\title{
Dióhéjban a Montessori-pedagógiáról a korai kétnyelvű nevelés tükrében
}

\author{
Hierholcz Tünde - Molnár Andrea \\ Montessori Mária Kétnyelvű Óvoda és Bölcsőde, Budapest
}

\begin{abstract}
Miért fontos és hasznos az idegen nyelvvel való ismerkedés az óvodás korosztálynál? Hogyan? Mikor? Anyanyelvi módszerrel, illetve Montessori-eszközökkel. A Mi Ovinkban a gyermekek vegyes életkorban való fejlesztése a Montessori-pedagógiában a következöterületeken történik: 1. Mindennapi élet gyakorlatai, 2. Érzékelés-fejlesztés, 3. Matematikai nevelés, 4. Kozmikus ismeretek, 5. Mozgás, zene, müvészet, 6. Anyanyelvi és idegen nyelvi nevelés. A nyelvi nevelés egyik lehetősége a Montessori-módszer szerint: Háromfázisú lecke bemutatásával, Montessori elvei alapján készített eszközök segítségével.
\end{abstract}

Kulcsszavak: L2-elsajátítás, koragyermekkori másodnyelv-elsajátítás, Montessorimódszer, A Mi Ovink, koraiangol-oktatás

\section{Napi rutin a Montessori Mária Kétnyelvű Óvoda és Bölcsődében}

Intézményünkben 2002 óta a 3-7 éves korosztály számára, 2007 óta pedig a 2-7 éves korú gyermekek számára folyik kétnyelvű nevelés Montessori-módszerrel. Mindezt a csoportban magyarul és angolul nevelő pedagógusok biztosítják a nevelési év minden napján. Az angol nyelvi nevelés egyrészt anyanyelvi módszerekkel, másrészt a Montessori-eszközök és szemléletmód segítségével történik.

Egész nap folyamán a gyermekek párhuzamosan két nyelvet hallhatnak: reggelizés, reggeli egyéni fejlesztés, kézműves tevékenységek, a feldolgozott Montessori-területhez kapcsolódó körfoglalkozások során, az udvari játék, az ebéd és pihenés ideje alatt, valamint ez folytatódik uzsonna időben és a délutáni játék során is.

A tehetséggondozó mühelyünkben az 5-6 éves gyerekek az iskolát megelőző évükben átmenetként, felkészítésként külön foglalkozások keretében, kis csoportban dolgoznak a csak angolul nevelő Montessori-pedagógussal. Itt lehetőség nyílik a beszélt nyelv további fejlesztésére, s az angol írott nyelvbe való bevezetésre a Montessoriangolos nyelvi eszközök segítségével.

\section{A gyermeki fejlődés fontos elemei}

\subsection{Az abszorbeáló lélek és az érzékeny periódusok}

Montessori Mária a gyermek életének első hat évét tartotta a legmeghatározóbb szakasznak. Ekkor beszélhetünk az abszorbeáló lélek fogalmáról: a gyermek fejlődése érdekében abszorbeálja a külvilágot, s az őt érintő információkat. Azokat megkérdőjelezés nélkül befogadja, magába szívja úgy, ahogy érzékeli. Különös tekintettel igaz ez a kultúrára, szokásokra, az anyanyelvre, illetve a hallott idegen nyelvre. Montessori azt is kiemeli, hogy a gyermekek ebben az időszakban érzékeny periódusokon mennek keresztül, amikor is különösen fogékonyak bizonyos információkra, tevékenységekre. A mozgás fejlődése mellett kiemelten fontos a nyelvi fejlődés is. 


\subsection{A pedagógus által elökészített környezet}

Montessori kiemelte az előkészített környezet fontosságát. Ez jelenti egyrészt az eszközök előkészítését: egyszerütől a bonyolult, konkréttól az absztrakt felé. A pedagógus, ismerve a Montessori-eszközök tárházát, illetve a módszertanát, a gyermeket megfigyelve, az ő igényeit, szükségleteit, érdeklődését követi. Ezen túlmenően biztosítja ebben a környezetben a gyermek szabadságát: szabad mozgás, szabad játékválasztás, beleértve a kérdezés, hibázás és felfedezések szabadságát egyaránt. Egy ilyen támogató közeg lehetővé teszi az ismeretek fogékony elsajátítását, beleértve a nyelvi kompetenciák fejlődését is.

Az előkészített környezet részeként fontos kiemelnünk a vegyes korcsoportok jelentőségét, hiszen a gyermekek egymást is segítik, támogatják egy ilyen közegben. Emellett a nyelvhasználat különböző, korosztályoknak megfelelő sajátosságaival is találkozhatnak.

\section{A Montessori-nevelés területei magyar és angol nyelven}

\subsection{A mindennapi élet gyakorlatai}

A „Segíts nekem, hogy magam csinálhassam” elv alapján a gyermekek önállóságát támogatjuk. Így megtanulhatnak magukról, illetve a környezetükről gondoskodni, miközben fejlesztik szem-kéz koordinációjukat, kéz- és ujj-ügyességüket, közvetve felkészítve a kezüket az írás tevékenységére is. Emellett fejlődik a szókincsük is mindkét nyelven. Ide tartoznak a teljesség igénye nélkül: öntés, csavarozás, csipeszhasználat, seprés, masnikötés.
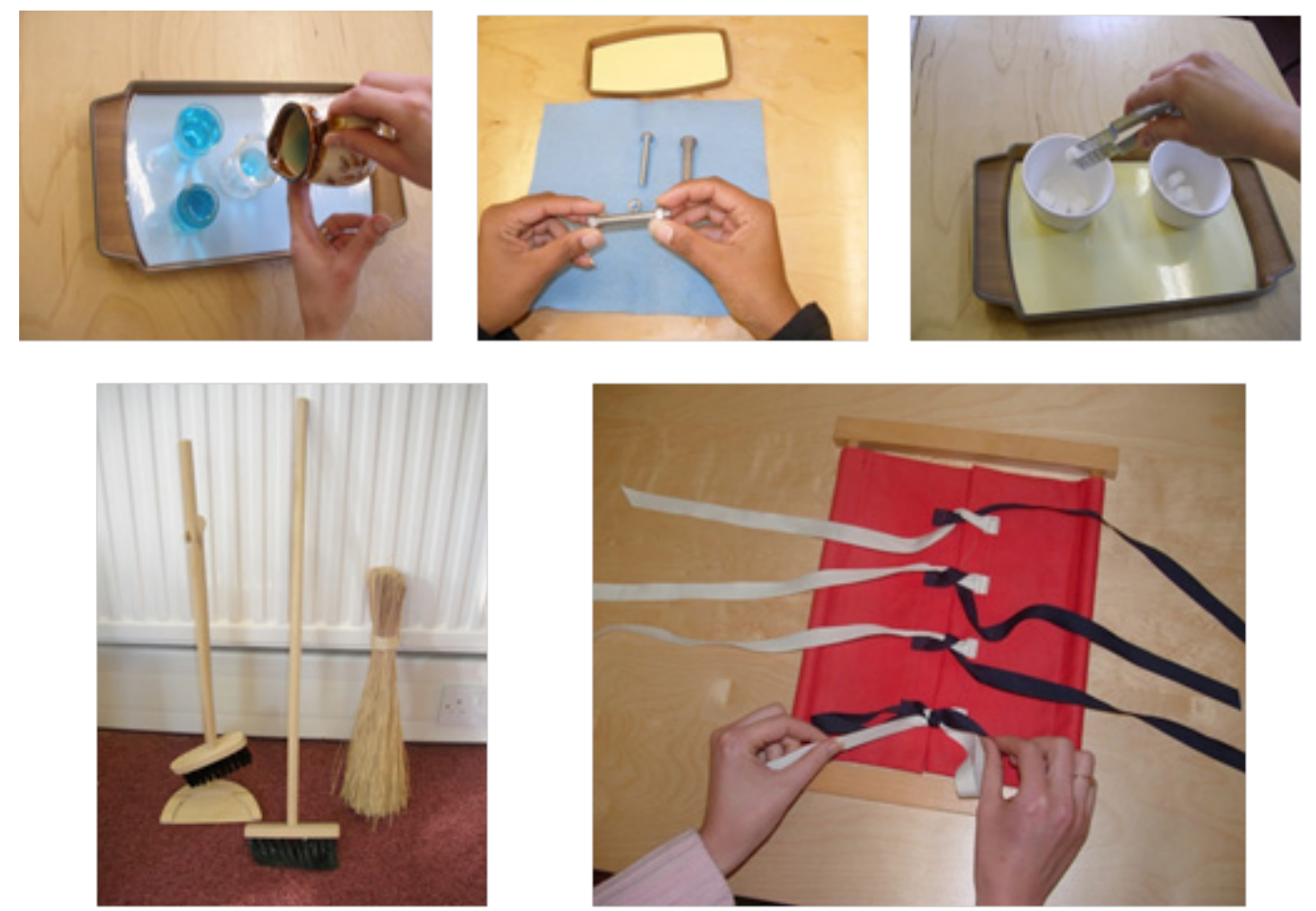

1-5. kép: A mindennapi élet gyakorlatai: öntés, csavarozás, csipeszhasználat, seprés, öltöztető keretek 


\section{Az érzékelésfejlesztés gyakorlatai}

A gyermekek életük első éveiben elsősorban az érzékszerveiken keresztül fedezik fel és ismerik meg a világot: látás, tapintás, hallás, szaglás, ízlelés útján. A Montessori-eszközök segítenek az érzékszervek világában eligazodni, s ezáltal az intellektus későbbi fejlődését megalapozni. Itt ismét lehetőség nyílik a szókincs nagymértékü bővítésére mindkét nyelven: elsősorban különböző melléknevek kerülnek megismerésre, amelyek leírják a bennünket körülvevő világot.

Néhány eszköz az érzékelésfejlesztés világából:

- a magasságot, szélességet, mélységet bemutató hengersorok, barna lépcsők és a rózsaszín torony, a kiegészító hengerek (nagy, kicsi, kisebb stb.), a hosszúságot bemutató piros rudak (rövid, hosszú, hosszabb),

- a háromszögek világába bevezető dobozok,

- a színek árnyalatait bemutató színdoboz (világos, világosabb, sötét stb.),

- a súlylapok (könnyü, nehéz, könnyebb, nehezebb), az érintő táblák (sima, érdes stb.),

- illetve a hangdobozok (hangos, halk, hangosabb, halkabb stb.).
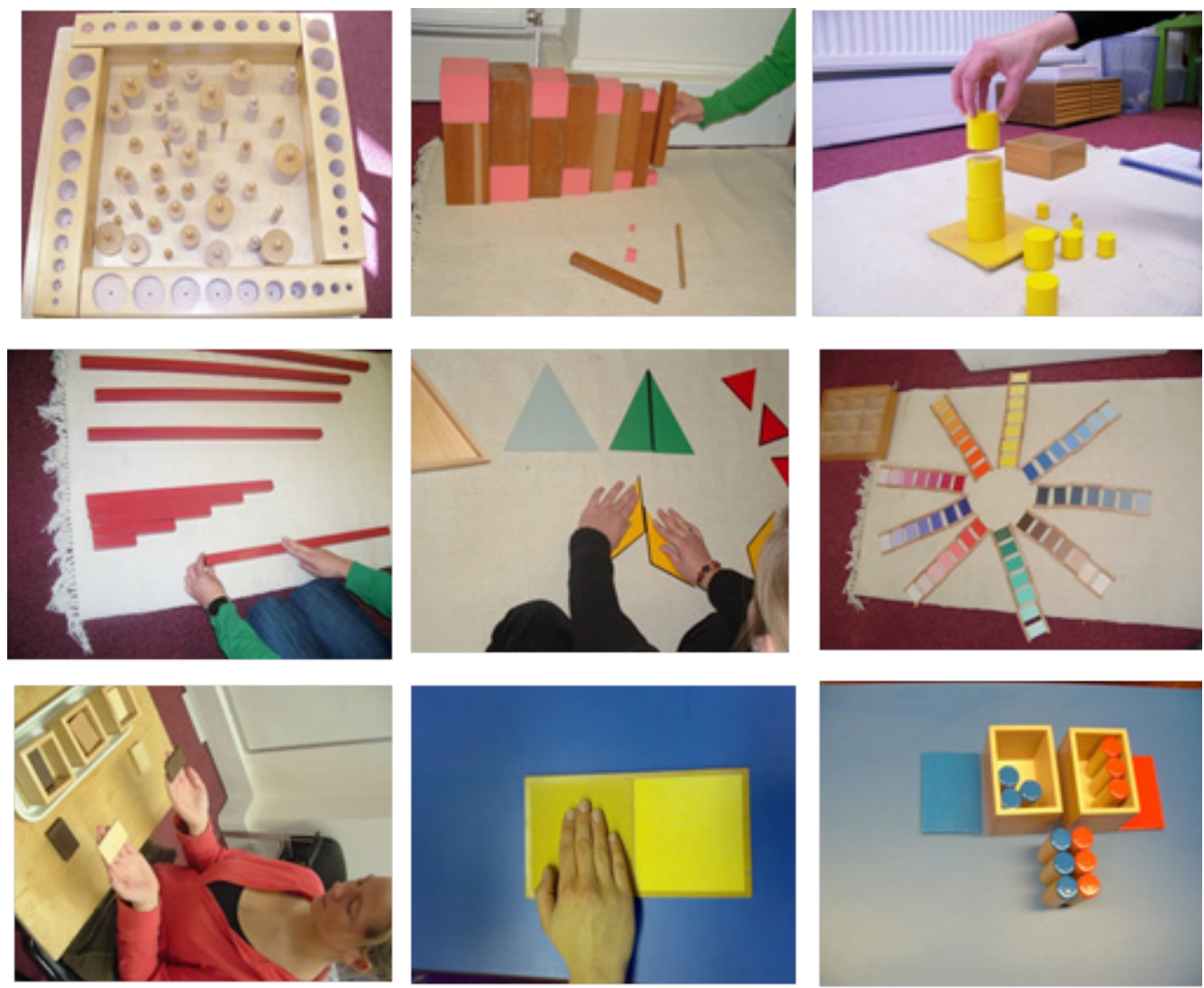

6-14. kép: Az érzékelésfejlesztés gyakorlatai: hengersorok, barna hasáb és rózsaszín torony, színes hengerek, piros rudak, konstruktív háromszögek, színdoboz, súlylapok, érintő táblák, hangdobozok

\subsection{A matematikai gondolkodás fejlesztése}

Az alkalmazott alapelvek és matematikai eszközök alapvetően a matematika (sorozat, rend, pontosság és precizitás) megértését teszik lehetővé: a gyermekek számára vonzó és érdekes eszközökön keresztül, melyek az egyszerütől a bonyolult, ismerttől az ismeretlen, konkréttól az elvont felé haladnak, cselekvéses tanulás segítségével, érzékszerveket bevonva, kezekkel való megtapasztalás által. 
Néhány eszközt említve, így ismerkednek meg a gyerekek játékosan a matematikával:

- A 0-10 fogalmával, beleértve a számképeket és mennyiségeket is a dörzspapírszámok, orsók, számrudak és -kártyák, számok és korongok segítségével.

- Matematikai múveletekkel: színes gyöngyök összeadáshoz, kivonáshoz, szorzáshoz, összeadástábla, kivonástábla, szorzótábla, osztótábla segítségével.

- Bevezetjük őket a tízes számrendszerbe (1000, 100, 10, 1), ahol nagy lelkesedéssel kalandoznak az ezresek birodalmában.

- Emellett a nagyok a törtekkel is ismerkedhetnek játékos formában.
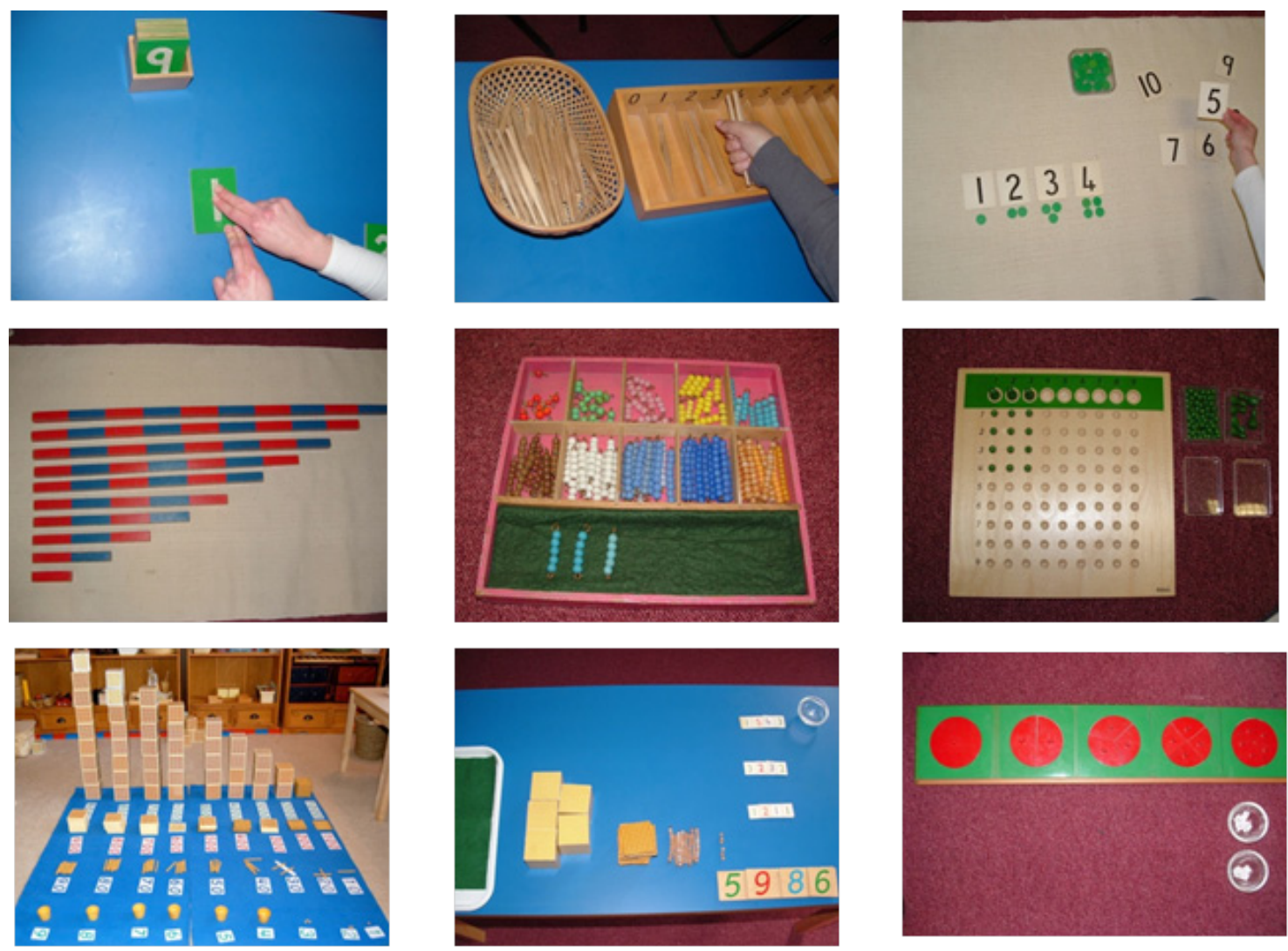

15-23. kép: Matematikai gyakorlatok: dörzspapírszámok, orsók, számok és korongok, nagy számrudak, szorzógyöngyök, szorzótábla, helyiértékes összeadás nagy számokkal, törtek

\subsection{Az anyanyelvi fejlődés}

A korábban bemutatott Montessori-eszközök használata közben fejlődik a gyermekek kommunikációs készsége, s emellett közvetlenül az írásra, olvasásra is felkészültté válhatnak (például szem-kéz koordináció, jobbról-balra haladás, fentről-lefele haladás stb.). Az anyanyelvi eszközök használata során közvetlenül is fejlődik a gyermekek beszéd-, írás- és olvasási készsége. Mindez nagymértékben megalapozza mind a beszélt, mind pedig az írott idegen nyelv ismereteinek további fejlődését, illetve fejlesztési lehetőségeit is. Ezt majd a későbbiekben az angol nyelvi nevelésnél kiemelten is láthatjuk.

Az eszközökböl néhányat kiválasztva:

- Ki kell emelnünk az írás-előkészítő sablonokat, melyek a gyerekek kezeit, ujjait ügyesítik meg, készítik fel az írásra.

- A dörzspapírbetűk segítenek a betükép rögzítésében, automatikussá válásában.

- A kimart betűk segítségével pedig ki tudnak rakni szavakat a gyerekek. 

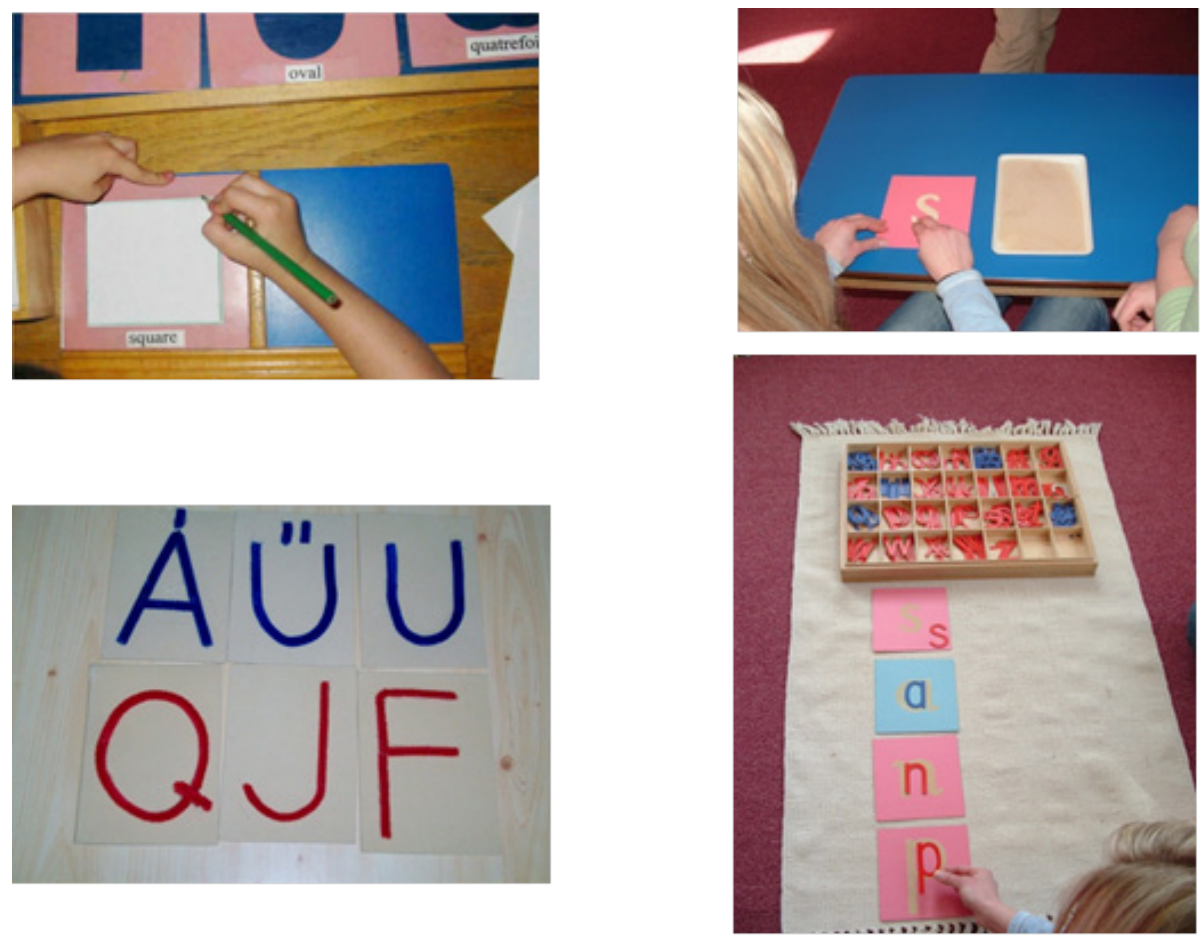

24-27. kép: Nyelvi eszközök: írás-előkészítő sablonok, dörzspapír betűkre variációk, kimart betűk

\subsection{A kozmikus nevelés}

A világról szerzett tudás által növekszik a tisztelet, a felelősségvállalás, a szeretet, a gondoskodás egymás, a többi élölény és a Föld iránt. A kozmikus nevelés célja a kozmikus terv megértése (együtt tudunk csak létezni), a kíváncsiság és érdeklődés felkeltése a világ dolgai iránt, a képzelet, a kommunikáció fejlesztése és felkészülés a későbbi tanulmányokra. A gyermekek számára nagyon érdekes és fontos területeken (állat- és növényvilág, bolygók, kontinensek, emberek és kultúrák stb.) fejlődhet a szókincsük mindkét nyelven. A kozmikus nevelés területei: botanika, zoológia, geológia, kísérletek és az idő bevezetése.

Néhány eszköz:

- életfolyamat-kártyák (például a béka, a katica fejlődése stb.),

- bolygók (föld, víz, levegő), kontinenstérképek, vízi és szárazföldi formák,

- ismeretek a Föld kialakulásáról,

- az óra bevezetése a gyermek egy napján keresztül. 


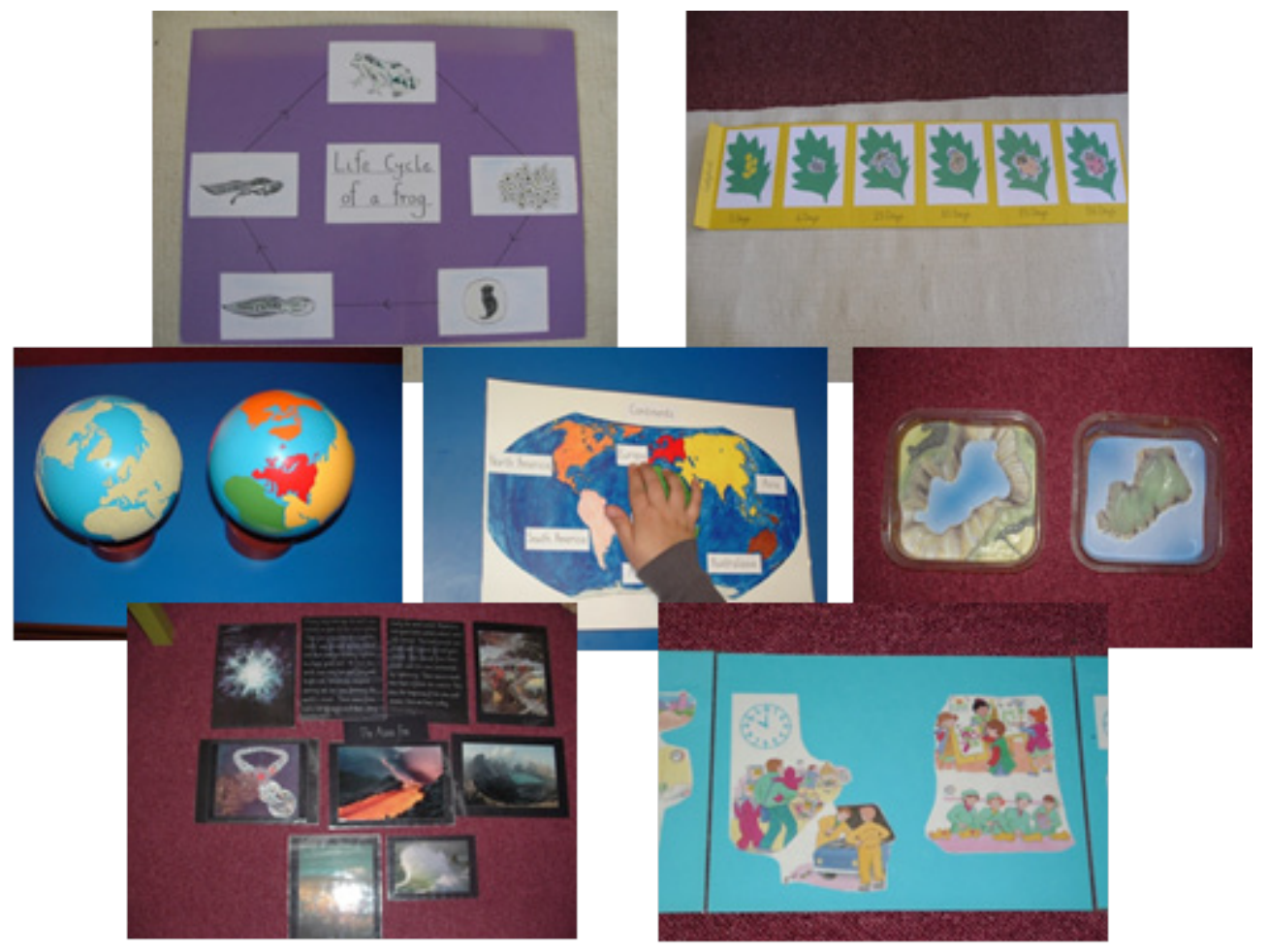

28-34. kép: Kozmikus nevelés: a béka élete, a katicabogár életciklusa, víz-szárazföld és kontinensföldgömb, a kontinensek neve, vízi és szárazföldi formák, a Föld kialakulása, egy gyermek napja

\subsection{Müvészeti, zenei és mozgásra nevelés}

Célunk, hogy a gyermekek - a nap bármely szakaszában, bármely témának megfelelöen - a kreativitást élvezetes módon tapasztalhassák meg, mindkét nyelven egyaránt. Minden évben két alkalommal, a karácsonyi (például bemutattuk, hogyan ünnepelnek a gyerekek a világ különböző részein) és az évzáró ünnepség (például különböző földrészekröl, különböző nemzetek szokásainak megjelenítése) keretein belül - a gyerekekkel közösen, az ő érdeklődési területüknek megfelelően -, feldolgozunk egy-egy témát színpadi előadás formájában (például a kontinensek élővilága, az állatok fejlödése).

Néhány példa a múvészeti, zenei és mozgásra nevelés területéről:

- Kézmüvesség: vágás, gyurma, ujjal festés, kréta, agyag, kollázs stb.

- Ének-zene: ritmus, tempó, egyenletes lüktetés, hangszerek, dalok és mondókák stb.

- Mozgás: nagymozgás, finommotorika, szenzotorna, szabad és strukturált mozgás lehetőségei stb.

- Dráma: történetek, mesék, dalok, projektek, elöadások stb. 

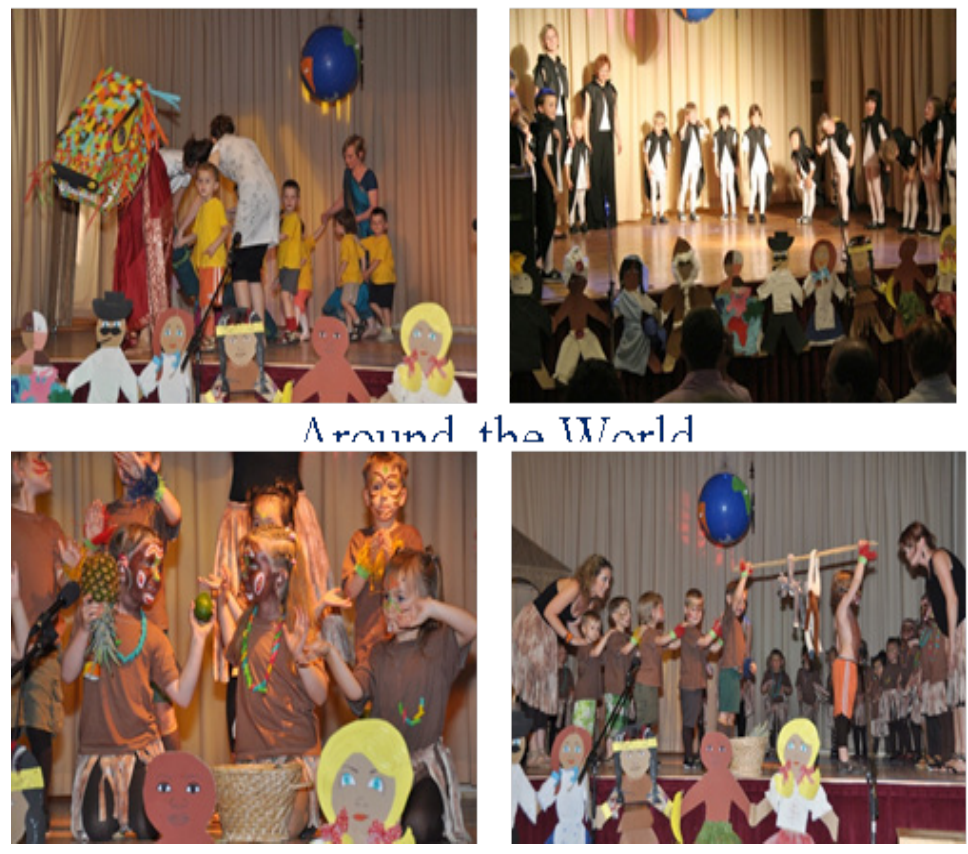

35-38. kép: A kozmikus nevelés színpadon megjelenítve: kontinensek világa

\section{Az angol-magyar kétnyelvű nevelésen belül az angol nyelv fejlesztése}

A két nyelven való nevelést már bölcsődei korban megkezdjük, s ez folytatódik az óvoda keretein belül is. Az angol nyelvi nevelés - elsősorban a beszélt nyelv elsajátítására irányultan - a korábban bemutatott Montessori-eszközök segítségével történik. Az írott nyelv elsajátításához, illetve a nyelvtani szerkezetek ismeretéhez pedig az angol nyelvi Montessori-eszközök nyújtanak segítséget.

Nyelvi nevelésünk a kéttanáros modellre épül. Az angolul és a magyarul nevelő pedagógus egymás munkáját kölcsönösen támogatja. A célnyelvi nevelésünkben a Montessori-módszer és -eszközkészlet mellett folyamatosan támaszkodunk a magyar óvodapedagógia anyanyelvi nevelésében alkalmazott módszereire, figyelembe véve a második nyelv értésének esetlegesen alacsonyabb fokát. A napi nevelés folyamatában folyamatosan részt vesz az angolul nevelő pedagógus is, a komplexebb magyarázatot kívánó nevelési helyzeteket a magyarul nevelő óvodapedagógus kezeli, az egyszerübb, érthetőbb szituációkat az angol nyelven nevelő oldja meg. A gyermekeket a dajkanyelv segítségével javítjuk ki:

Gyermek: „He house there.” (Ö ház ott.)

Pedagógus: „I see: His house is there.” (Ó értem, az ő háza ott van.)

A nyelvi fejlesztéshez használt technikák: dalok, versek, mondókák, történetek, történet-kártyák, dráma, szituációs helyzetek (szókincs kontextusban), könyvek, számítógépes játékok. Külön kiemelnénk a szókincsbővítés módszerét, melynek kidolgozása Montessori nevéhez kapcsolódik: a három fázisú lecke (tárgyak/kártyák). Ezzel a módszerrel egyszerre 2-4 új szót tudunk bevezetni a gyermek számára anyanyelven, illetve idegen nyelven egyaránt.

Az első lépcsőben izoláltan megnevezünk egy tárgyat/képet: „This is a triangle.” "This is a square." "This is a rectangle."1 Ezeket felváltva ismételjük párszor. A második

1 Ez egy háromszög. Ez egy négyzet. Ez egy téglalap. 
lépcsőben mind a három tárgy/kép a gyermek előtt helyezkedik el. Ebben a szakaszban történik meg a bevésődés a tárgyak/képek felismerésére, illetve a szókincs ismétlése által. „Put the triangle on your right knee.”2 A harmadik szakaszban ismét izolálva mutatjuk be a tárgyakat/képeket, de most a következő kérdést tesszük fel: „What is this one?”3 Végül pedig összefoglaljuk, hogy mi mindent tanult a gyermek, s felhívjuk a figyelmét a környezetében ennek a szókincsnek a megjelenésére. „You have learned the names of the triangle, square and the rectangle. Can you see a rectangle on the wall?"4 etc.

Természetesen az sem probléma, ha egy-egy alkalommal csak a második lépcsőig jutunk, azt nyugodtan ismételhetjük majd a következő nap, akár az elejétől is. A lényeg, hogy mindig a gyermeket figyeljük, s az ő igényei alapján tervezzük a tevékenységeket. Fontos továbbá megemlítenünk az ismétlés és a pedagógus személyiségének, illetve szókincsének jelentőségét is.

Felmerülhet a kérdés, hogy hova juthatunk el a háromtól hatéves korig terjedő időszakban a két nyelven való nevelés ilyen, óvodai formájában.

- Megértésben: szituációk, kulcsszóstratégia, gyakran hallott utasítások, egyszerűtől az összetett mondatok megértéséig, nagy passzív szókincsig.

- Beszédben: egyszavas válaszoktól - a rutin mondatokon keresztül - az önálló rövid mondatok használatán át, egészen a helyes nyelvtani szerkezetek ( 6 éves kor) alkalmazásáig.

- Írás, olvasás területén: fonetikus szavak mellett nyelvtani szabályok is bevezetésre kerülhetnek játékos formában.

\subsection{Az angol nyelven való írás fejlesztése}

A Montessori módszer alapján és a tapasztalataink is ezt mutatják, érdemes az írást az olvasás előtt bevezetni, amennyiben 5 éves kor alatti gyerekekkel ismertetjük meg a betűket. A mozgás és a nyomhagyás öröme erős motivációval bír. A betűk és az általuk jelképező hangok megismerését szolgálják a dörzspapírbetűk.

\subsubsection{Közvetett fejlesztés}

Egyrészt példamutatással tudjuk felkészíteni a gyerekeket (például üzenetet hagyunk egymásnak egy játék keretein belül, képeslapot küldünk egy beteg kisgyereknek stb.). Másrészt a már említett Montessori-területek eszközeinek használata során felkészülnek a gyerekek a balról jobbra, fentről lefele irányok használatára, valamint fejlődik a szem-kéz koordinációjuk, ami elengedhetetlen az íráshoz.

\subsubsection{Közvetlen fejlesztés}

A fonetikus szavak írását irányítottan az angol nyelvi Montessori-eszközök használatával vezetjük be. Fontos figyelembe vennünk, hogy az írás egyrészt a motorikus képességekből (betűk formázása), másrészt az intellektus munkájából áll (szavak leképezése).

Az írást segítő eszközök közül néhány:

- I Írás-előkészítő sablonok, melyek a kéz ügyesítését segítik elő.

- Dörzspapírbetűk, melyek a betük formázását tanítják.

\footnotetext{
2 Tedd a háromszöget a jobb térdedre.

3 Mi ez?

${ }^{4}$ Megismerted a háromszöget, négyzetet és a téglalapot. Látsz a falon téglalap formát?
} 
- „I spy” -játékhoz tárgyak, melyekkel a kezdő, a közbülső és az utolsó hangok "meghallását" gyakorolhatják a gyerekek. "I spy with my little eyes, something beginning with p. Pig? Pot? Pan? I spy with my little eyes, something ending with "t". It is a pot. or I spy with my little eyes something with "i"sound in the middle."

- A mozgatható $A B C$, mely az intellektust fejleszti: tárgyak, majd képek mellé kirakják a szóképeket.

- S végül, mikor már képesek egyedülálló betüket leírni, illetve a szóképeket kirakni, akkor hirtelen azon veszik észre magukat, hogy nehézség nélkül le tudnak írni szavakat.
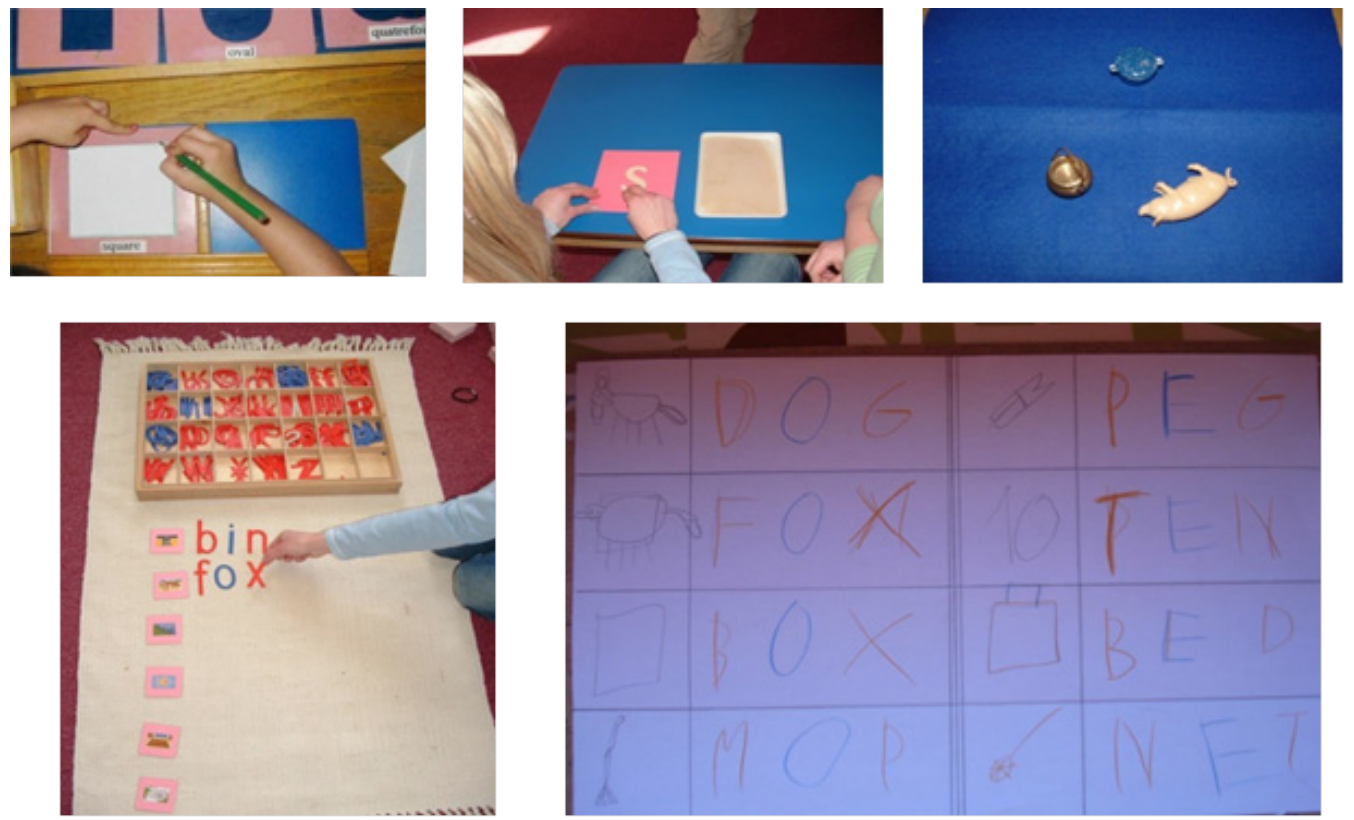

39-43. kép: Îrás-előkészítő sablonok, dörzspapírbetűk, „I spy”-játék, nagy mozgatható ABC és a kimart betük, szavak kirakása a nagy mozgatható $A B C-v e l$

\subsection{Az angol nyelven való olvasás bevezetése}

\subsubsection{Közvetett fejlesztés}

A példamutatás szerepét itt is hangsúlyoznánk (például "Let's read what we will have for lunch today!" stb.). Fontos, hogy a gyermekek lássák, hogy különböző céllal olvashatunk: információszerzés, szórakozás stb. A gyermekekkel el szoktunk menni az ovis könyvtárba, s együtt kölcsönzünk ki könyveket. Ennek dokumentálása persze az írásra is példamutatást ad. Emellett a berendezési tárgyak, eszközök mind magyarul, mind pedig angolul szóképekkel vannak ellátva a csoportszobában. Fontos azt is, hogy a gyerekek nevét használjuk - fürdőszobában, szekrényükön, rajzaikon stb. - jelek helyett.

\subsubsection{Közvetlen fejlesztés}

A teljes Montessori-eszközkészletre jellemző, hogy meghatározza a tanítás lépéseit is. Így nem csupán a gyerekek számára nyújt segítséget a különböző képességek fejlődésében,

\footnotetext{
${ }^{5}$ Látok valamit, ami „p” hanggal kezdődik. Pipa? Pap? Papír? Látok valamit, ami „„” hanggal végződik. Kút? Tat? Tét? Látok valamit, amiben a szó közepében van „e” hang. Meggy?

${ }^{6}$ Lássuk csak, mi is lesz ma az ebéd!
} 
de a módszert alkalmazó pedagógusnak is támpontokat ad a fejlesztéshez. Ez a pontos felépítettség jellemzi az olvasástanításhoz szükséges készletet is. Átlátható, tagolt, és az előkészített környezet elvének megfelelően, sorrendben elhelyezett demonstrációs eszközökröl van szó, melynek alkalmazásával az egyszerütöl haladunk az összetettebb szavak olvasásáig. Ez az alapelv, a kiejtésbeli egyszerüség, amely miatt a hárombetüs, fonetikus szavakkal kezdjük az olvasást. Nagyobb sikerélménnyel jár. A magyar anyanyelvű gyerekek esetében továbbá a dekódolást segíti, ha az első szókészlet többnyire főnevekből áll.

\subsubsection{1. „Pink” eszközök}

A rózsaszín kóddal ellátott eszközök a három betűből álló, fonetikus szavak olvasását segítik. Az olvasási folyamat motorikus részét könnyíti meg a két mássalhangzó között egy magánhangzó típusú szavak olvasása, a dekódolást pedig a főnévi tartalom segíti, így elsőként tárgyakat kapcsolunk össze a hozzájuk tartozó szóképpel. A szavak olvasását segíti, ha egy kicsit a transzferhatásra építve, hasonló hangzású, hasonló mássalhangzókból álló, vagy rímelő szavakat olvastatunk egymás után: pot, rod, pig, peg, fox, box, mug, rug, cat, bat.

A következő lépés a „Mysterybox”, ahol nincsen sem kép, sem tárgy, csak az előző dobozban lévő eszköz szóképei, kibővítve újabb, eddig olvasatlan, de szintén hárombetüs és fonetikus szóképekkel is: big, wet, sit, got, run, lot, hot, fun stb.

A szótáblák, szólisták már meghatározott sorrendet követnek, kép, illetve tárgyi megerősítés nélkül, és bár jelentéssel bírnak ezek a szavak, pusztán olvasási gyakorlatként funkcionálnak.

A kifejezéskártyák már bepillantást nyújtanak a nyelvtanba, fonetikus szószerkezetek olvasásával: a red bus, a big van stb.

Ezeken a fokozatokon haladva a gyerekek számára mindig egy kis kihívást jelent egy-egy olvasási játék.

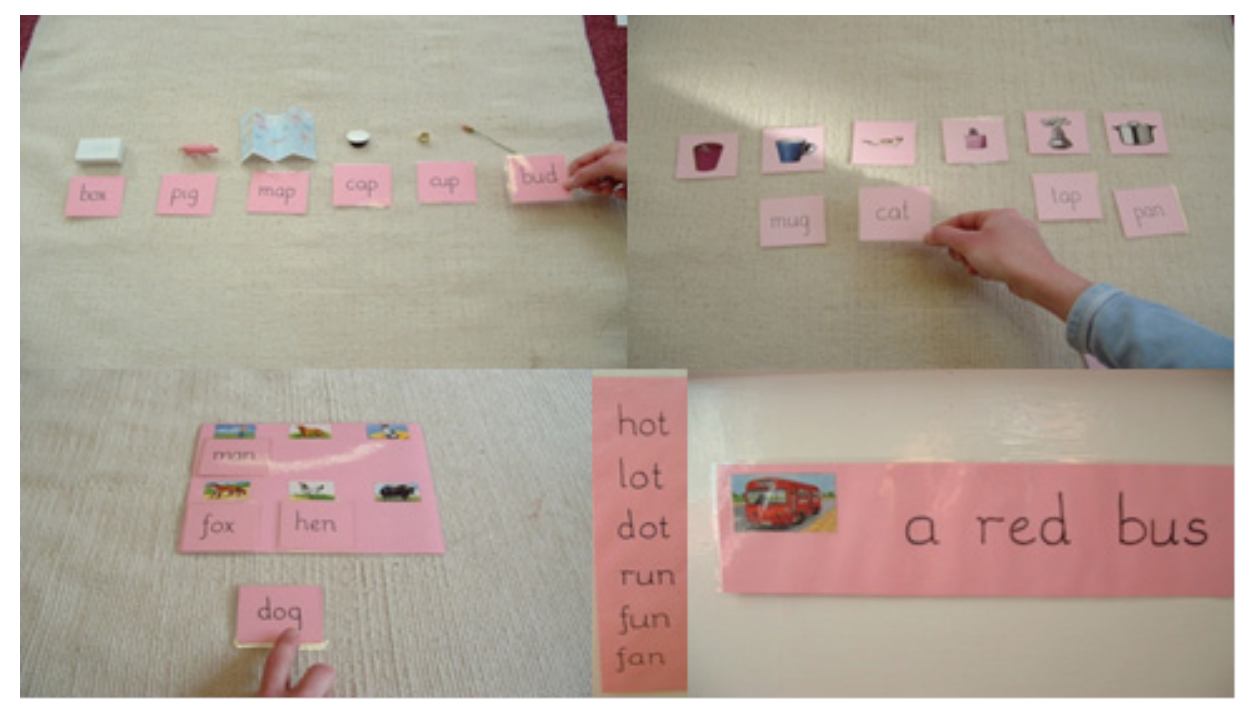

44-48. kép: Pink eszközök: három betủs fonetikus szavak olvasása tárgyakkal, majd képekkel, három betűs fonetikus kártyák, három betűs fonetikus szólista, három betüs fonetikus szószerkezetek

\footnotetext{
7 Varázsdoboz
} 


\subsubsection{2. „Blue” eszközök}

A kék színű eszközök négy vagy több betüböl álló szavak olvasását gyakoroltatják, illetve a hozzájuk kapcsolódó szabályszerűségekre mutatnak rá. A lépések hasonlatosak a rózsaszín eszközkészlethez.

A kék kártyakészlet részét képezik azok a szavak is, melyekben időlegesen egymás mellé kerül két vagy három mássalhangzó. Elsőként a szó elején van a mássalhangzó-kettőzés (twig, frog, pram), aztán a szó végén (next, jump), végül a szó elején és végén is (stamp, dress). Fokozatosan haladva a három mássalhangzó torlódásával bíró szavak, majd a dupla mássalhangzós kifejezések kerülnek sorra.

A kék kifejezés kártyák már mondatokat tartalmaznak. Itt is a képek segítenek az értelmezésben:

The frog sits on the log., The rabbit hops and jumps. ${ }^{8}$ stb.

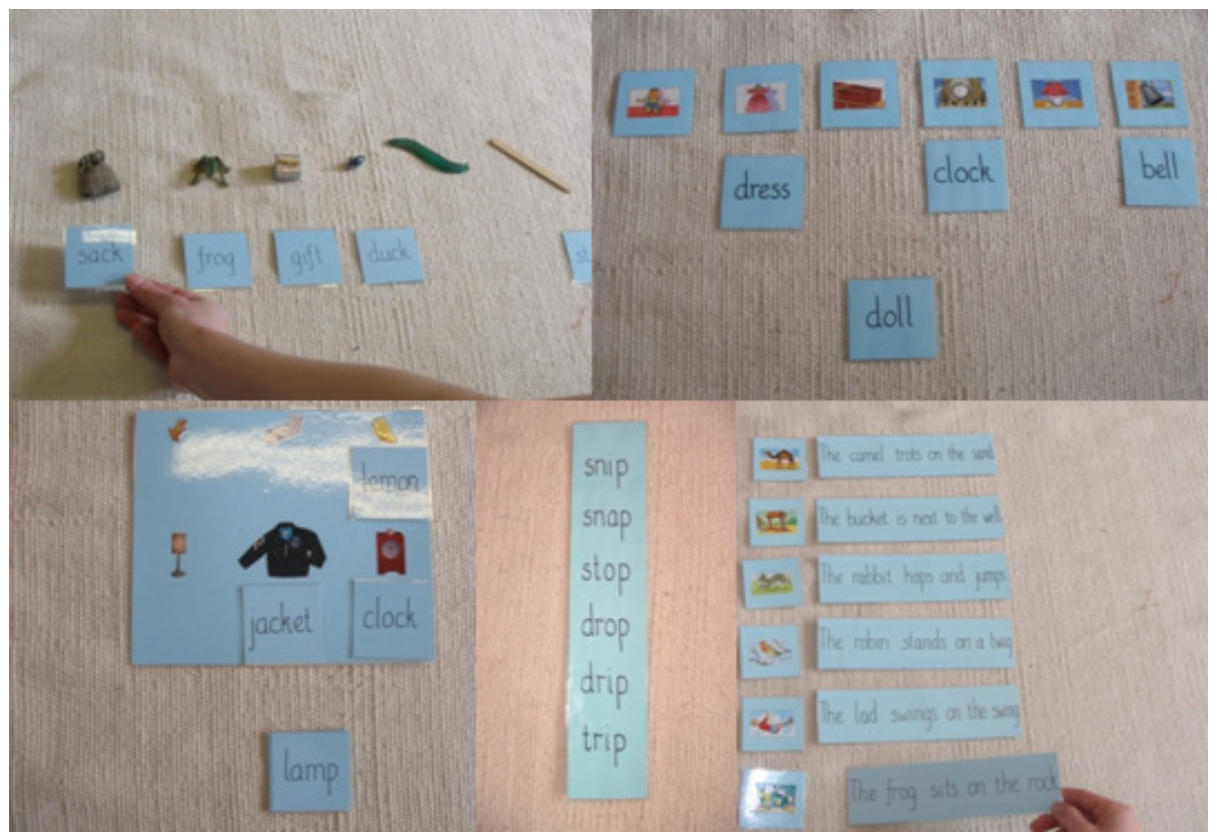

49-56. kép: Kék eszközök: egyszerübb szabályok bevezetése kék kártyákkal (kártyák, mondatok).

\subsubsection{3. „Green” eszközök}

Ezek az eszközök az együtthangzókat hivatottak gyakorolni. Mivel az angol nyelvben 44 hang és 26 betű áll rendelkezésre, ezért van szükség rájuk. Elöször csak a következő, egyszerübb együtthangzók kerülnek bevezetésre az alábbi mondat kíséretében: "If you can see these two letters together, you say..."9

- sh: fish, shop, ship, shell, dish stb.

- ch: chick, chips, lunch, witch stb.

- th: thin, think, moth, cloth stb.

Az eszközök a korábbiakhoz hasonló módon készülnek. Itt külön színnel kiemeljük a tanított fonémát, ezzel is segítjük az olvasást és a rögzítést. A szólistán egy kis

\footnotetext{
${ }^{8}$ A béka a farönkön ül. A nyúl ugrabugrál.

${ }^{9}$ Ezeket a betüket egymás mellett úgy olvassuk, hogy:...
} 
kép segíti, hogy milyen hangot kell hallatni, ezzel is lehetővé téve az önállóságra nevelést, az önálló olvasást, a sikerélményt. Ezen korai együtthangzók után, továbbiakat is be lehet vezetni például: ai (rain), oa (goat), ee (feet), oo (book) stb.

A gyakorlatban azt láttuk, hogy ez a kétnyelvü óvodai nevelés keretein túlmutat. $A$ magyar anyanyelvü, óvodás korú gyermekekkel eddig általában nem jutunk el, viszont az eddigi alapokra építve az általános iskola alsó tagozatában már része lehet az angoltanítás folyamatának.

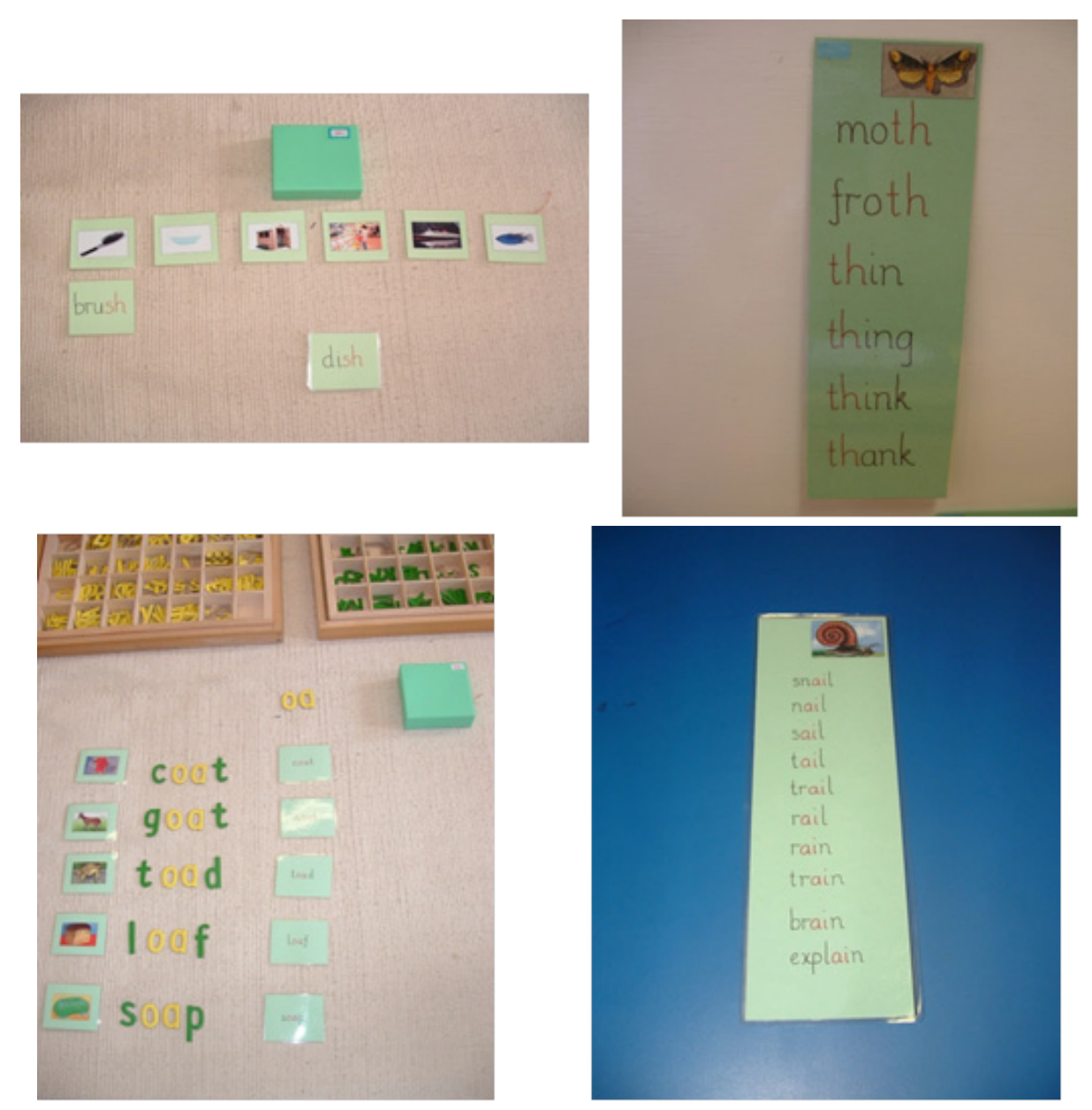

57-60. kép: Green-eszközök: fonogramok bevezetése (tárgyakkal és képekkel, fonogram- szólista)

\subsection{Az angol nyelvtan bevezetése}

Hatéves kor körül játékos, mozgással egybekötött módon, színkódolt eszközök segítségével (a szósorrend elősegítésére) bevezetésre kerülhet a csoport munkájába az angol nyelvtan. A szóképek természetesen megfelelnek a gyermek olvasási képességének, szintjének: használhatunk három-betűs, fonetikus szavakat, illetve használhatunk hosszabb szavakat, esetleg már együtthangzókat is, amennyiben ennek a tudásnak már birtokában van a gyermek.

\subsubsection{A főnevek bevezetése}

Ide soroljuk a tárgyakat, a környezetünkben lévő játékot, illetve az egyes és többes szám bemutatását szolgáló eszközöket. 

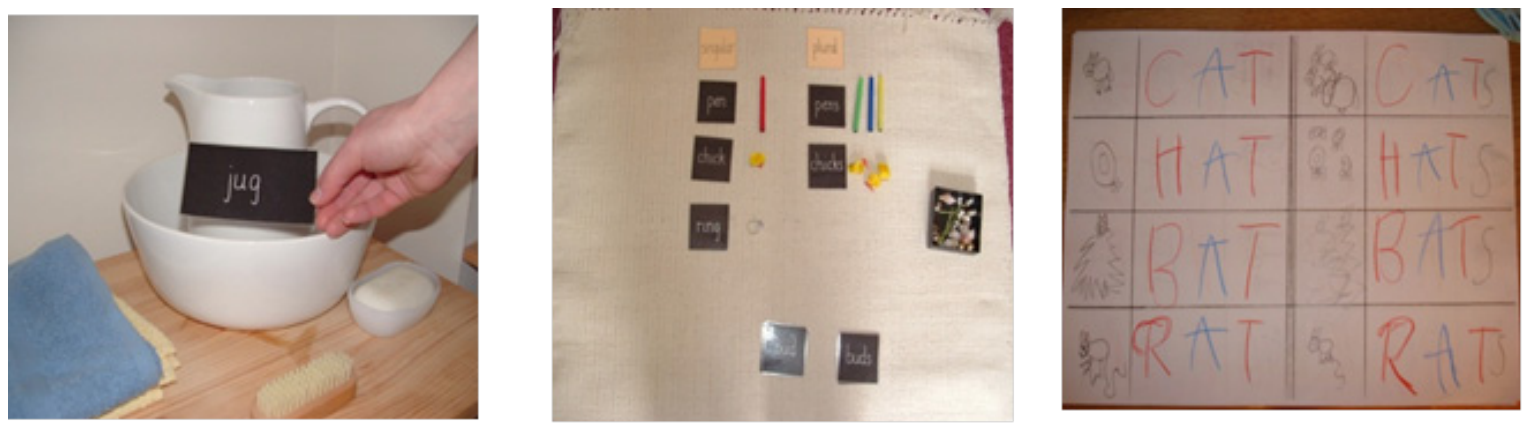

61-63. kép: Nyelvtani gyakorlatok: főnevek bevezetése, egyes és többes szám

\subsubsection{A melléknevek bevezetése}

A melléknevekkel való ismerkedés során megtanulják a gyermekek, hogy a melléknevek arra szolgálnak, hogy egy tulajdonságot írjanak le. Megtanulják, hogy nem minden melléknév kapcsolható össze mindegyik fönévvel. Nagyon jókat lehet nevetni az olyan játék során, mikor véletlenszerủen párosítjuk össze a mellékneveket a fönevekkel (például sickbus). Emellett azt is megtanulják a gyerekek, hogy egy-egy fönevet több melléknévvel is körbeírhatunk.

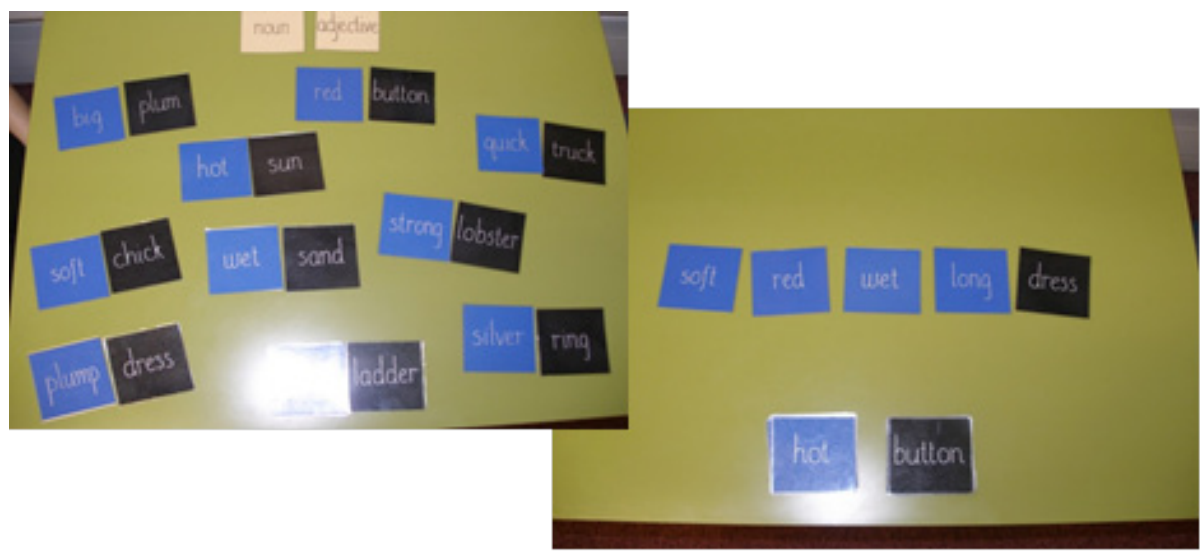

64-65. kép: Nyelvtani gyakorlatok: melléknevek bevezetése

\subsubsection{Az igék bevezetése}

Dalos, mozgásos formában - testünket bevonva, ezáltal is segítve a rögzítést, s élvezetesebbé téve a játékot - ismerhetik meg a gyerekek az igéket. Kísérhetjük ezeket a szavakat például a "This is the way I clap my hands"10 dallal. Itt is érvényes, hogy egyszerütöl a bonyolult felé haladunk: a „pink”, majd „blue”, majd pedig a „green” szabályoknak megfelelő igéket vezetjük be a gyermek olvasási képessége alapján.

\footnotetext{
10 Így mosunk kezet
} 


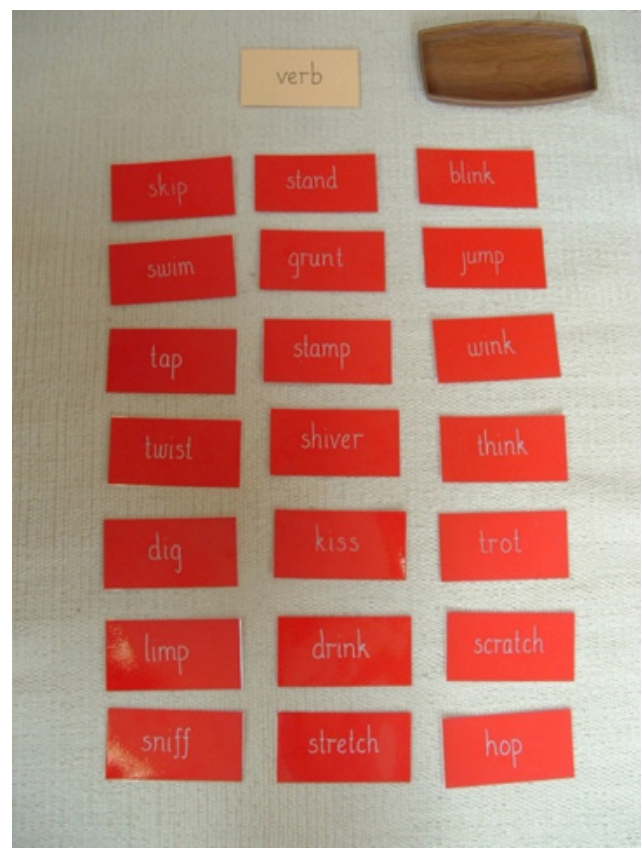

66. kép: Az igék bevezetése

\subsubsection{Az elöljárószavak bevezetése}

Szintén játékos formában - tárgyakat használva, testrészeinket bevonva - történik ezen nyelvtani részbe való bevezetés is. A színkódolt eszközök segítenek a mondat szósorrendjének szabályait bemutatni: „The chick is in front of the chair."11

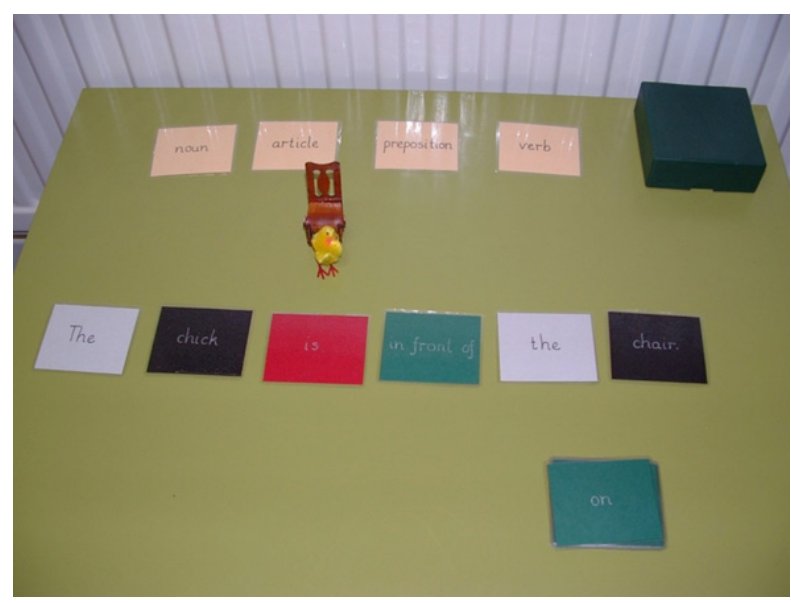

67. kép: Az elöljárószavak bevezetése

\subsection{5. Összefoglaló gyakorlat: a farm}

A gyermekek több héten keresztül eljuthatnak a teljes mondat alkotásához, felhasználva a különböző szófajokat: a tárgyat, fönevet, névelöt, melléknevet s végül az igét. Mondatalkotás során itt is jókat szoktunk nevetni a gyerekekkel együtt.

\footnotetext{
11 A csibe a szék előtt van.
} 


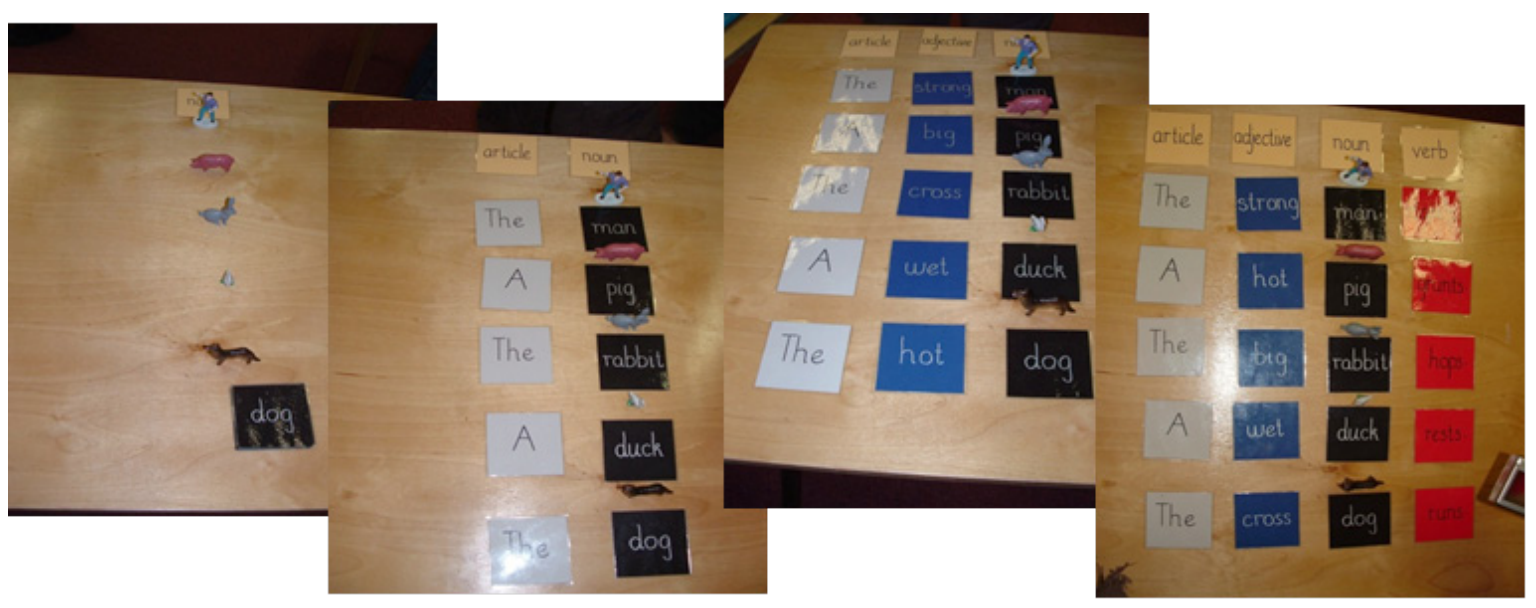

68-71. kép: Összefoglaló gyakorlatok (fönevek, névelök, melléknevek, igék)

\section{Következtetéseink az óvodai kétnyelvű neveléssel kapcsolatosan}

Gyermekeink az egész napos nevelés folyamán hallják az idegen nyelvet, lehetővé téve, hogy a mindennapi kommunikációjukban is használják (például a rutin mondatokat: „Can I go to wash my hands?” 12 stb.). A nyelvelsajátitás - az eszközök és a módszer segítségével - nem tudatosan, hanem játékosan történik: szinte szívják magukba az idegen nyelvi formulákat és nyelvtani sajátosságokat. A gyerekek ugyanazon nyelvelsajátítási sablonokat használják, mint a saját anyanyelvük tanulásánál - tudattalanul, de elemzik a nyelvet -, hiszen a két nyelvet párhuzamosan, gyakorlatilag egy időben tanulják.

Itt kell, hogy megemlítsük a Montessori-óvodánkra és a -pedagógusokra jellemző elfogadó-támogató légkört. Az alkalmazott módszerek és eszközök mellett nagyon fontos az az atmoszféra, melyben a visszahúzódó gyermekek is képesek kibontakozni. Emellett koruknál fogva is könnyebben és bátrabban szólalnak meg, mert nem alakulnak még ki a pubertás korra jellemző gátlásaik a szerepléssel kapcsolatban.

Nem mellékes érv az sem a korai nyelvtanulás mellett, hogy egy óvodáskorú gyermek artikulációs bázisa még rugalmas, nem egy, a saját anyanyelvére zárt halmaz, így könnyebben sajátít el olyan fonémákat, amelyek saját nyelvére nem jellemzőek. Így kiejtésük közel anyanyelvi szintü lesz.

\footnotetext{
12 Kimehetek kezet mosni?
} 